\title{
Profile
}

\section{Tunde Kelani: The Man Exceeds the Frame}

\author{
Toyin Falola \\ University Distinguished Teaching Professor \\ Jacob Frances Sanger Mossiker Chair in the Humanities \\ The University of Texas at Austin \\ toyinfalola@austin.utexas.edu
}

The extraordinary announcement, coming from the Federal University of Agriculture, Abeokuta, that ace filmmaker Kelani will now be based there as a Fellow is heartwarming. The news reveals the warmth and uniqueness of the University's boundless imaginations and the humanistic vision of its Vice-Chancellor, Professor Kolawole Salako. The news of this deserving appointment follows on the heels of Kelani receiving the prestigious Léopold Sédar Senghor Prize for African Cultural Creativity and Impact in July, 2019 at the annual TOFAC event at Babcock University. In that same month, he was also inducted into the American Oscars-the Academy of Motion Picture, Arts and Sciences. All of these accolades are well-deserved. Kelani has spent his career putting things-people, ideas, cultures, traditions, and ideologies-inside the cinematographic frame. It is a most exciting thing to see him too bursting out of every frame with all these multiple achievements that celebrate him. İrókò!

\author{
İókò Olúwéré! \\ Ộrọ bàmibà ní gbénú İrókò. \\ Igi t’ọmọ aráyé ń gbóṣùbà rẹ!! \\ Kokoko lára. \\ Àjífẹnu kíkò pè. \\ Oba igi lóko! \\ Ợ rọ hùnnùhùnnù ní í gbénú igi tó le koko. \\ Kò bojú wẹhìn \\ Káyé ó tẹńbẹlù ẹ rí. \\ Igi tí i dá jìnnijinni sộmọ́ ojo láyà! \\ Olúwéré ni baba igi lóko.
}


Olúwéré that resides in İrókò tree!

It is a terrific gnome that dwells inside İrókò

A tree the mankind cannot but praise!

A very strong tree

That must be addressed with a unified force

The king of trees in the forest

The mumbles expressions reside in a tree as tough as İrókò

There has never been a time it turns to look back

And find people making a mockery of it

A tree that intimidates the coward!

Olúwéré, the lord of the trees in the forest. ${ }^{1}$

Tunde Kelani, popularly referred to as TK, is to Nollywood, the Nigerian/ African movie and entertainment industry, what Wole Soyinka is to literature. These are people of greatness that have crept out from underneath the ancient Olumo Rock. To be widely acknowledged as the most respected filmmaker in Nigeria, or anywhere, against the tormenting odds of uncontrolled piracy, bad economy, sanctions due to political differences and unsupportive leadership, is no little feat to achieve. Kelani has consistently positioned himself as a cultural ambassador, socio-political commentator, and future-oriented creative icon with his filmic productions, and other engagements, all of which are conscience-driven.

TK, a world-class storyteller and director of so many films, hails from Abeokuta in Ogun State. From a cultural viewpoint, Kelani is a cultural educator and an advocate whose works have become a narrative of success and hard-work. From his early works such as The Dilemma of Reverend Father Michael which was co-produced by the movie veteran Adebayo Faleti, who was himself the author of the Yoruba play, İdààmú Páàdì Múkáílù, Kelani has been a steady yet prolific writer, photographer, cinematographer, and movie producer. In his repertoire of works, Aníkúrá, İyá Ni Wúrà, İwà, Thunder Bolt, Ti Olúwa Ni Ilè, Ó Le Kú, Kòṣeégbé, Agogo Ėèwọ, Șaworoidẹ, etc., Kelani has been an advocate of culture, pushing the Yoruba culture to the frontiers of knowledge. He has taken upon himself the duty of an historian to capture, preserve, refract and re/present the African cultural heritage through the lens of his camera. İrókò!

1 This and other English translation of the praise poetry excerpts in the profile are provided by Gabriel Ayoola of the Department of Comparative Literatures, University of Georgia at Athens. 
Ėèyàn bí İrókò!

Irókò bi èèyàn!

Igi tígí i wárí fún!

Túndé Kèlánì.

Adúmádéyin.

Òfọoọ-àrà-gbé-kámẹrá-mú-fìmù yááyi!

Gíwá, oba onísinnimá!

Tọjú-tẹyin ni dùndún fi í ríran:

Tọ́jú-tẹyin ní bàtá fí í fọhùn.

Eèkánnà ọmo Kélání,

Irun orí omo Kèlání,

Àtáñò̀kò ọmọ Kèlání -

Gbogbo ara ọmo Kèlání

Ní i gbé fiìmú àrà jáde!

Man like İrókò!

Irókò like man!

The tree highly respected by other trees!

Túndé Kèlání

Black with teeth as white as snow.

With dexterity, he handles the cameras in film productions!

The Leader, the king of the film producers

Dùndun drum functions with both sides of its face:

Bàtá drum makes its rythmn with both sides of its face.

The son of Kelani's finger nails

The hairs of his head

His thumbs-

The whole body of Kèlánís son

Produce many amazing films!

After so many productions and cinematography voyages, Kelani's company, Mainframe Film and Television Productions (established in 1992) has produced some of the most outstanding movies in Nigeria and Africa while also offering services and technical support to other outfits. Tunde Kelani's productions include documentaries on different subjects. Many of Kelani's works are a mixture of tradition and modernity as the movies adapt the language of modern technology and traditional materials such as language, oral poetry, myths, legends, and folktales, and aesthetic and ornamental endowments of the Yoruba orality and knowledge system. At the front burner of productions like Campus Queen and Arugbá is the message to embrace 
modernity into traditional culture in order to sustain the latter and benefit from the former.

The ability of Kelani to seamlessly blend tradition and modernity, both at the production and preoccupation level, has marked him out amongst his peers as a forerunner and maestro of the industry. Although he has been acknowledged as the bridge between the old and new Nollywood, and in fact, as a pioneer figure of New Nollywood, like Láaróyè, he has on several occasions denied being a part of what has been popularly perceived as Nollywood. It is not strange that he is still an "outsider" in Nollywood, as the depth of his oeuvre defies the unsophisticated productions that still characterize much of Nollywood. For Kelani, culture is not static and antique; it evolves and in its evolution are the resolutions to the present predicaments bedeviling our society. Hence, whenever Kelani makes bold commentaries on the socio-political existence of the nation, he proffers (local) solutions. İrókò!

Túndé to mójú kámẹrà,

Tí i pe kámẹrà rán níṣẹ.

Bó sùn,

Kámẹrà rẹ kò ní yàyàkuyà.

Bó yaju, bó ń najú lẹnu isẹ,

Kò sí nínú oníyàkuyà.

Túndé knows camera so well

That he commands them at will

Even in his sleeps

His camera will never miss its good shots

While awake, even if he is relaxing

He never shoots amiss.

TK had a very rich cultural background that has greatly influenced his career. This illustrious background and his technical education in film production culminated in the brilliant consistency that defines the legacy of his works. In the development and production of cinema and films (and entertainment) in Nigeria, TK is a leading figure. His career continues to add to the bulging growth of this sector. His contributions to our emerging national identity and culture are immense and indispensable. Down to his personality, TK is always dressed in African traditional attire, especially àdire, which is indigenous to his hometown, Abeokuta, where he had his childhood experiences that inspire and further shape his creativity as a film producer and director. His education at the London Film School and Western Nigeria Television has equipped this talented man with unique techniques and knowledge 
in film-making and directing. The TV programs Arambada and Tunmigbe were also supported by Kelani as part of his burgeoning career in cinematography. İrókò!

Ọ̀kunrin mẹta tí í fọwọ àrà gbé fímù àrà jáde.

Yóo máa jộra wọn ni:

Òsùpá ò lè jọ̀ ràwọ ní sánmọ.

Afọgbọ́n inú kọgbộn jọ fáyé.

Adúmádéyín tí wọn ń jowú rẹ nígbà gbogbo.

A versatile man that produces wonderful films

It may look alike

The moon can never be like stars.

His impetus he combines with experience to teach the world good lessons. Adúmádèyín, the envy of all.

Kelani's knowledge in filmmaking and cinematography, and his love for superb literature, have sparked the adaptations of literary works into movies that widened the horizon of the Nigerian literary space. TK's collaboration with writers and artists across genres has generated a new hybrid of film productions that has deepened Nollywood's focus and professionalism. For example, Dazzling Mirage, a novel by Olayinka Egbokhare, was adapted into a movie by Kelani's Mainframe Productions, and that production has helped to create more awareness in the Nigerian space about sickle cell anemia and its effects. With many other adaptations like Ó Le kú, The White Handkerchief, Campus Queen and Màami, Kelani has pushed forward significant socio-political and economic preoccupations projected by the artists, but in a more relatable manner through his audio-visual filmic productions. The coalescing of traditional and cultural values with high technological dexterity in his movies has launched the director-cum-cinematographer to the limelight in the world. Kelani's works and films also have cultural and political ideologies which have traced the historical and political growth of the nation, Nigeria.

In recognition of his illustrious contributions to the society and achievement as an artist, TK has been recognized both nationally and internationally with many awards and recognitions that span so many years or films and works of his career. These include:

- Africa Magic Viewer's Choice (AMVCA) Industry Merit Award in 2018;

- Léopold Sé dar Senghor Prize for African Cultural Creativity and Impact, 2019;

- Member of the Emmy Awards International Jury in 2015; 
- Elected to vote in the Directors Category of the Board of the Academy of Motion Picture Arts and Sciences in 2019; and

- Nigeria Merit Award Lifetime Achievement Award in 2014.

These awards and recognitions are particularly due to Kelani's inimitable craft and contributions to the advancement of the Nigerian filmmaking industry, and cultural values distilled in his works. As part of his intellectual contribution to the industry, he established the Mainframe Film and Media Institute to educate and train artists in professional cinematography, editing, directing, scriptwriting, etc. within the advanced theory and art of filmmaking. This institute has been established to promote cultural values and also improve the socio-economic output of the nation. With the Mainframe Film and Media Institute, TK has further established himself as a visionary leader with the aim to impact the society and the younger generation more. The Institute becomes a symbol to pass on his legacy and brilliancy to as many as possible, an orientation that is most lacking in Nigerian society.

Kelani is arguably one of the greatest pioneers of the filmmaking industry in Nigeria and Africa whose person and works have been the subject of many doctoral theses and books. The 71-year old filmmaker is celebrated nationally and internationally for his grand narratives about African culture and art. The man Kelani and his art will continually spark admiration and intellectual discourses on the political, cultural and philosophical productions of the Nigerian space both in the literary universe and film industry.

The appointment at the Federal University of Agriculture, Abeokuta will provide him a unique opportunity to contribute to the diffusion of creativity, the linkages of sciences, technology and culture, and the training of future leaders in a dynamic world in an age of expanding possibilities. T-K's tentacles will spread beyond his current reach. When it rains, it pours. Òjò İbùkún dé! Iré wọlé!! İrókò!!!

Kò séégun tó lára lẹsẹè bii Lébe.

Ta ni mojú fìmù bí Túndé Kèláni,

Gíwá tó jọba wọn?

İtákùn tó șe é dimọ gòkè.

İrókò, ọba igi lóko!

No masqurades can dance as Lébe

Who knows about film productions as Túnde Kèlání

The leader, the king of all?

A ladder that help people go up.

İrókò, the king of trees in the forest! 
Are we surprised of the man TK has been able to make of himself? We will not be surprised when we also think of the noble lineage of the man which shows he is not only greatness born, but also greatness made. TK belongs to the Kúlódò lineage through whom a whole oral poetic form, Ềsà (the Privileged) became part of the rich Yoruba cultural heritage. It will therefore be befitting to end this piece with the praise of this living legend:

The illustrious Onígbórí scion of Kúlódo’

Scion of Kúló dò Awùsí Ẹyọ

Scion of the hunchback that praises the king

Scion of the lineage deep in the way of knowledge

Babátúndé, you are the scion of Kúlódò Awùbi

The abundant water that splits into creeks -

From Aàsà, to Ẹkorọ, to Dòbo'dè

And Afúnlẹ́lẹ, the clean brook of queens

The dance of yesterday is not enough

The whips of yesterday pain no more

Bring us the dancing and whipping masquerades again

It is our father's rite we are doing

Invoke the spirit of Arúkú,

The cadaver in the cloth called ẹkú

Invoke the spirit of Ológbojo,

Custodian of eight hundred masquerades.

İróko! 